\title{
Greenhouse Gas Emissions from Landfills: A Case of NCT of Delhi, India
}

\author{
Singh SK, Anunay G ${ }^{*}$, Rohit G, Shivangi G and Vipul V
}

Department of Environmental Engineering, Delhi Technological University, Delhi, India

*Corresponding author: Anunay G, Assistant Professor, Department of Environmental Engineering, Delhi Technological University, Delhi, India, Tel: +91-11-27871018; E-mail: anunaygour@live.in

Received date: Feb 09, 2016; Accepted date: Mar 03, 2016; Published date: Mar 19, 2016

Copyright: $\odot 2016$ Singh SK, et al. This is an open-access article distributed under the terms of the Creative Commons Attribution License, which permits unrestricted use, distribution, and reproduction in any medium, provided the original author and source are credited.

\begin{abstract}
The quantity of municipal solid waste (MSW) generated in Delhi is increasing at an alarming rate. Presently Delhi generates 8360 tons per day of MSW, which is projected to rise up to 18,000 tons/day by 2021. This would place immense pressure on the existing infrastructure and soon become a challenge for the local and municipal bodies responsible for waste management. The paper surveys the present state of the solid waste management in the NCT of Delhi and the propagation of greenhouse gas from the landfill sites. The bulk of the waste generated in Delhi is disposed at the three landfill sites viz. Bhalswa, Ghazipur, and Okhla. Waste at landfills is acted upon chemically and biologically to yield stabilized solids, liquid leachate and gases. The degradable organic carbon in the waste is broken down by microorganisms into methane gas which is released as a major contributor to global anthropogenic $\mathrm{CH}_{4}$ emissions. The paper further calculates the GHG emission potential for the three landfill sites in Delhi using IPCC Methodology - Default Method and First Order Decay Model. The results obtained from both the methods are compared and it is found out that Default Method gave higher GHG emission values than the First order decay model. MSW in Delhi has been found to have enormous waste-to-energy potential, which if employed may cater to Delhi's energy needs and simultaneously reduce the GHG emissions.
\end{abstract}

Keywords: Municipal solid waste; Landfill; Greenhouse gas; GHG emissions; IPCC - default method; IPCC - FOD method

\section{Introduction}

Solid waste management have become a worldwide problem and is getting increasingly complicated day by day mostly due to the rise in population, industrialization and the consequent changes introduced in the lifestyle of people. Hence the per capita generation of solid waste bears strong correlation with the economic development at global as well as local scale. There are six functional elements complementing solid waste management (SWM) practices. It takes off with waste generation, followed by storage and handling of waste at source, waste collection, transfer and transport, followed by treatment and transformation, and at last the disposal [1]. Presently majority of the waste generated is disposed in open dumps or ordinary landfills in the developing rural areas or in sanitary landfills in the developed ones. Of the various SWM techniques, landfilling is found to be the cheapest and easiest to dispose municipal solid waste (MSW) all over the globe [2]. With the increasing urbanization and evolving life styles, Indian cities are generating eight times more MSW compared to that generated during 1947. Annually about 90 million tons of solid waste is produced as by-products of industrial, mining, municipal, agricultural and other activities. While the average collection efficiency in metropolitan cities (population $>1$ million) is below $70 \%$ and that for smaller cities, it is less than 50\% [3-5]. Waste at the landfills have been known to be one of the major sources of anthropogenic greenhouse gas (GHG) emission and a key contributor to global warming [6]. Methane $\left(\mathrm{CH}_{4}\right)$ emission from landfill is estimated to account for $3 \%-19 \%$ of the anthropogenic sources in the world [6]. India, one of the world's largest emitter of $\mathrm{CH}_{4}$ from landfills, currently produces about 16 tons of $\mathrm{CO}_{2}$ equivalent per year which is predicted to increase to almost 20 tons of $\mathrm{CO}_{2}$ equivalent per year by 2020 [7]. $\mathrm{CH}_{4}$ alone constitutes about $29 \%$ of the total GHG emissions in India which is nearly twice the worldwide average of $15 \%$. Moreover the emission from wastes is also twice $(6 \%)$ than the global average of $(3 \%)$ [8]. Major part of MSW constitutes of biodegradable organic materials, which undergo anaerobic decomposition in landfills generating a variety of gases collectively called landfill gas (LFG). It is composed of approximately $60 \%$ methane $\left(\mathrm{CH}_{4}\right)$ and $40 \%$ carbon dioxide $\left(\mathrm{CO}_{2}\right)$ in concert with low amounts of non-methane organic compounds and other trace gases [9-11]. Both $\mathrm{CH}_{4}$ and $\mathrm{CO}_{2}$ are GHGs. Over a time period of 100 years, the global warming potential (GWP) of $\mathrm{CH}_{4}$ is 25 times of the GWP of $\mathrm{CO}_{2}$ and has an atmospheric residence time of $12 \pm 3$ years [12]. Moreover percolating rainwater through the landfills produces leachate which contaminates the ground water [13,14]. Presently, approximately 8360 tons of MSW is generated daily in Delhi, out of which $87 \%$ is collected which amounts to 7273 tons per day (TPD). Moreover of the collected 7273 TPD of waste only $28 \%$, i.e., 2000 TPD is treated [15]. As only one waste to energy plant at Timarpur - Okhla with a capacity of 1950 MTD is operational.

\section{State of Municipal Solid Waste Management in Delhi}

Population of Delhi is increasing at an alarming rate and it is estimated that the waste generation is expected to touch 18,000 TPD by 2021 [16]. State of the Delhi's landfills is not very encouraging with all the landfills being used way beyond their design life. Bhalswa landfill (BL), Ghazipur landfill (GL) and Okhla landfill (OL) are the three operational landfill sites in Delhi while two landfill sites in Jaitpur and Bawana are proposed. MSW is treated at three composting plants at Bhalswa, Narela / Bawana and Okhla; two incineration plants at Okhla which also generates $16 \mathrm{MW}$ of power from the waste; one RDF plant at Narela / Bawana; and one construction and demolition waste dump at Burari [17]. Also all the three landfill sites have crossed the 30 metre height ceiling. Since landfills are major contributor of methane emissions [16], emissions from waste-water treatment plants $[18,19]$ 
Citation: Singh SK, Anunay G, Rohit G, Shivangi G, Vipul V (2016) Greenhouse Gas Emissions from Landfills: A Case of NCT of Delhi, India. J

Page 2 of 6

and other waste management practices have not been considered in scope of the present study.

\section{Study area}

The NCT of Delhi is spread over an area of 1483 sq. km., located in the northern part of India. It is divided into three parts Delhi Ridge, Yamuna flood plains and plains. The air quality is poor and highly variable $[20,21]$. Hence periodic critical assessment of air quality by analytic and statistical tests is necessary [22]. It is the hub for employment for millions from the periphery, i.e., the NCR. As a result of which a huge mass of population survive in Delhi, which produces huge quantity of waste. Literature related to MSW management in Delhi shows that wastes are handled by three municipal agencies namely, Municipal Corporation of Delhi [23], New Delhi Municipal Corporation (NDMC) and Delhi Cantonment Board. All the MSW generated in the city is transported to landfill sites at Ghazipur in East Delhi, Bhalswa in North Delhi and Okhla in South East Delhi [16]. Brief descriptions about these landfills are given in (Table 1).

\begin{tabular}{|l|l|l|l|}
\hline Characteristics & Bhalswa (BL) & Ghazipur (GL) & Okhla (OL) \\
\hline Starting year & 1992 & 1984 & 1996 \\
\hline Location & $\begin{array}{l}2844^{\prime} 27.16^{\prime \prime} \mathrm{N}, \\
779^{\prime} 27.92^{\prime \prime} \mathrm{E}\end{array}$ & $\begin{array}{l}2837^{\prime} 22.4^{\prime \prime} \mathrm{N}, \\
7719^{\prime} 25.7^{\prime \prime} \mathrm{E}\end{array}$ & $\begin{array}{l}2830^{\prime} 42^{\prime \prime} \mathrm{N}, \\
776^{\prime} 59^{\prime \prime} \mathrm{E}\end{array}$ \\
\hline Area (Hectare) & 26.22 & 29.62 & 16.89 \\
\hline Slope () & $60-70$ & $60-70$ & 7080 \\
\hline Average height (m) & 18 & $25.5-30.5$ & $27-40$ \\
\hline Dumping quantity (TPD) & 1500 & 2200 & 1200 \\
\hline Type of waste & $\begin{array}{l}\text { Household, vegetable market, C and D } \\
\text { waste }\end{array}$ & $\begin{array}{l}\text { Household, animal waste from poultry, } \\
\text { fish market and slaughter house }\end{array}$ & Mainly household with C and D waste \\
\hline Zones supplying waste & $\begin{array}{l}\text { Civil Lines, Karol Bagh, Rohini, Narela, } \\
\text { Najafgarh and West }\end{array}$ & $\begin{array}{l}\text { Shahdara (North andWest), City zone, } \\
\text { Sadar Pahargunj, NDMC }\end{array}$ & $\begin{array}{l}\text { Central, Najafgarh, South Delhi and } \\
\text { Cantonment Board }\end{array}$ \\
\hline Depression, below ground level (m) & 4 & 3 & 4 \\
\hline
\end{tabular}

Table 1: Salient features of Delhi's landfills [16].

All the landfills have been receiving waste from more than 15 years; with GL being the oldest site operating since 1984; followed by BL which started in 1992 and OL became operational in 1996. Based on the municipal records, it has been estimated that the cumulative waste quantities reached at GL, BL and OL landfills till 2008 - 2009 are 11 million tons, 9.2 million tons and 6.1 million tons respectively [16]. Figure 1 shows a five-point summary and comparison of the quantity of solid waste received at BL, GL and OL landfill sites on a logarithmic $\mathrm{y}$-axis of the box plot.

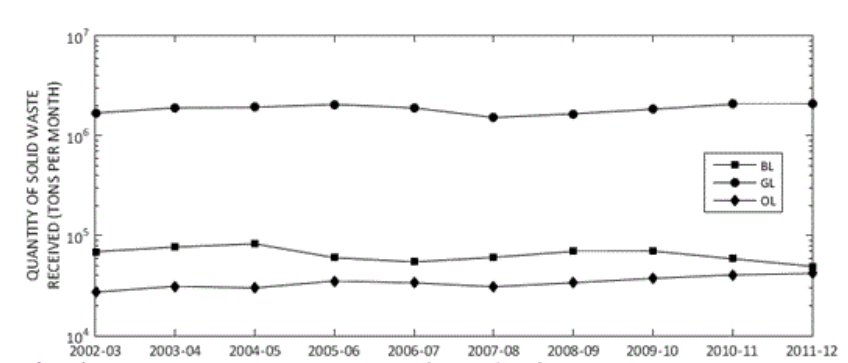

Figure 1: Box plot for quantity of solid waste received by BL, GL and OL landfill sites.

Overall trend of quantity of solid waste received at the landfill sites have been found to be increasing (except OL). Figure 2 shows the annual variation in average monthly garbage received at BL, GL and OL sites from year 2002 to 2012 .

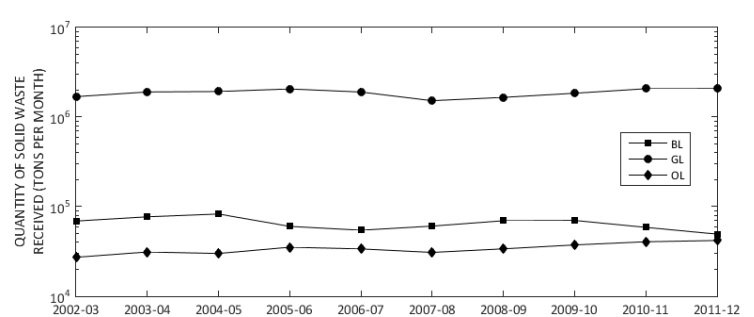

Figure 2: Annual variation in average monthly garbage received at $\mathrm{BL}, \mathrm{GL}$ and $\mathrm{OL}$ sites.

\section{Composition}

The composition of MSW is the key to estimate the GHG emissions from landfills. Table 2 shows the relative content of various parameters of Indian MSW. It reveals that the amount of recyclables is very less in the waste owing to the rag-pickers who pick up recyclable matter (paper, plastic, glass, and metal) at dhalaos (garbage bins) before the waste reached the landfill [24]. 
Page 3 of 6

\section{Methane Emission from Landfills: Methodology for Inventory Estimation}

Due to disposal of solid waste to landfills, emissions of methane take place due to anaerobic decomposition of organic matter. IPCC suggests two methods for calculating methane emissions from landfills.

The Default IPCC methodology based on the theoretical gas yield (a mass balance equation).

Theoretical first order kinetic methodologies, through which the IPCC Guidelines introduces the 'First order decay (FOD) model'.

\begin{tabular}{|l|l|l|}
\hline Sr. No & Parameter & Content (\%) \\
\hline 1 & $\begin{array}{l}\text { Biodegradables (includes green matter, kitchen } \\
\text { waste, paper, textiles, dry leaves) }\end{array}$ & 73.7 \\
\hline 2 & $\begin{array}{l}\text { Recyclables (includes glass, rubber / leather, metal, } \\
\text { plastic) }\end{array}$ & 9.2 \\
\hline 3 & Inert (include concrete, sand, brick, stone) & 17.1 \\
\hline 4 & Others (includes dead animals, etc.) & 6.3 \\
\hline 5 & Moisture & 47 \\
\hline
\end{tabular}

Table 2: Composition of waste reaching the landfill site in Delhi [23].

The main difference between the two methods is that method IPCC-Default method does not reflect the time variation in solid waste disposal and the degradation process as it assumes that all potential methane is released the year the solid waste is disposed whereas the effect of timing of the actual emissions is reflected in FOD method [25].

\section{IPCC Default method}

The method assumes that all the potential methane emissions are released during the same year the waste is disposed. The method is simple and emission calculations require only input of a limited set of parameters, for which the IPCC Guidelines provide default values, where country-specific quantities and data are not available.

The Default Method is based on the following equation:-

Methane emissions $(\mathrm{Gg} / \mathrm{yr})=\left(\mathrm{MSWT}^{*} \mathrm{MSWF}^{*} \mathrm{MCF} * \mathrm{DOC} *\right.$ $\left.\mathrm{DOCF}^{*} \mathrm{~F}^{*} 16 / 12-\mathrm{R}\right) *(1-\mathrm{OX})$

Where,

\begin{tabular}{|l|l|l|}
\hline Symbol & Parameter & Value \\
\hline MSWT & $\begin{array}{l}\text { Total municipal solid waste (MSW) } \\
\text { generated (Gg yr/yr.) }\end{array}$ & $\begin{array}{l}\text { MSWT * MSWF = Waste } \\
\text { disposed at landfill site (see } \\
\text { Tables 4-6) }\end{array}$ \\
\hline MSWF & $\begin{array}{l}\text { Fraction of MSW disposed of at the } \\
\text { disposal sites. }\end{array}$ & 0.6 (IPCC default value) \\
\hline MCF & Methane correction factor & 0.77 (IPCC default value) \\
\hline DOCF & Fraction DOC dissimilated & 0.5 (IPCC default value) \\
\hline DOC & $\begin{array}{l}\text { Fraction of degradable organic } \\
\text { carbon in the waste }\end{array}$ & $\begin{array}{l}\text { Fraction of methane in the landfill } \\
\text { gas }\end{array}$ \\
\hline F & 0.5 (IPCC default value) \\
\hline
\end{tabular}

\begin{tabular}{|l|l|l|}
\hline$R$ & Recovered methane $(\mathrm{Gg} / \mathrm{yr})$ & $\begin{array}{l}\text { Recovery of LFG is not } \\
\text { adopted in India, hence the } \\
\text { value is zero }\end{array}$ \\
\hline OX & Oxidation factor & 0 (IPCC default value) \\
\hline
\end{tabular}

Parameters and values of the equation are tabulated above.

\section{Methane generation by first order decay method}

The amount of methane generated from the landfill site is calculated based on a First Order Decay Model. In this method, methane generation in the landfill is described as a function of time. Nationally adjusted FOD model has been used for calculating yearly emissions from the waste dumped in landfills.

$$
\mathrm{QT}, \mathrm{x}=\mathrm{k}{ }^{\star} \operatorname{MSWT}(\mathrm{X}){ }^{*} \operatorname{MSWF}(\mathrm{X}){ }^{*} \operatorname{MCF}(\mathrm{X}){ }^{\star} \operatorname{Lo}(\mathrm{X}){ }^{*} \mathrm{e}-\mathrm{k}(\mathrm{T}-\mathrm{X}) \text { * }
$$

$\mathrm{F}$

Where,

\begin{tabular}{|c|c|c|}
\hline Symbol & \multicolumn{2}{|c|}{ Parameter } \\
\hline QT, $x$ & \multicolumn{2}{|c|}{$\begin{array}{l}\text { The amount of methane generated in the current year from waste } \\
\text { disposed in the year } X\end{array}$} \\
\hline$x$ & \multicolumn{2}{|c|}{$\begin{array}{l}\text { The historical year of the disposal of the relevant national MSW } \\
\text { quantities }\end{array}$} \\
\hline K & \multicolumn{2}{|c|}{$\operatorname{Ln}(2) / t^{1 / 2} .(1 / y r)$ and $t^{1 / 2}$ is half-life period for degradation process } \\
\hline $\operatorname{MSWT}(\mathrm{X})$ & \multicolumn{2}{|c|}{ Total MSW generated $(\mathrm{Gg} / \mathrm{yr})$ in year X } \\
\hline $\operatorname{MSWF}(\mathrm{X})$ & \multicolumn{2}{|c|}{ Fraction of MSW disposed to solid waste disposal sites in year $\mathrm{X}$} \\
\hline $\operatorname{MCF}(X)$ & \multicolumn{2}{|c|}{ Methane correction factor (fraction) for year $\mathrm{X}$} \\
\hline \multirow[t]{3}{*}{$\operatorname{Lo}(X)$} & \multicolumn{2}{|c|}{$\begin{array}{l}\text { DOC x DOCF for the year } \mathrm{X}\left(\mathrm{Gg} \mathrm{CH}_{4} / \mathrm{Gg} \text { waste }\right) \\
\text { Where: }\end{array}$} \\
\hline & $\mathrm{DOC}$ & Fraction of degradable organic carbon in the waste \\
\hline & DOCF & Fraction DOC dissimilated \\
\hline $\mathrm{T}$ & \multicolumn{2}{|c|}{ The current year (year of the emission estimate) (Gg/yr) } \\
\hline
\end{tabular}

Parameters of the equation are tabulated above.

The value of is taken as 7 years (default value) for tropical countries and rest all parameters have same values as that in IPCC default method.

\section{Results and Discussion}

IPCC- Default methodology and IPCC-FOD methodology has been utilized to yield the values of net methane emission from the three landfills at Bhalswa, Ghazipur and Okhla. Table 3 shows the descriptive statistics, geometric increase / decrease occurred in the average monthly solid waste received at the landfills over the years 2002 to 2012. It also presents the correlation of quantities of solid waste received, which indicates stronger correlation between GL and OL than others. This may be due to the geographic proximity of the landfills, similarity in generation, logistics and transport of wastes. Bhalswa Landfill is the fastest growing landfill as the solid waste received here is growing at a rate of $9.61 \%$ per year. Whereas the solid waste received at Okhla Landfill is declining i.e. at a negative growth rate. The quantities of solid waste received at the respective landfills are 
Citation: Singh SK, Anunay G, Rohit G, Shivangi G, Vipul V (2016) Greenhouse Gas Emissions from Landfills: A Case of NCT of Delhi, India. J

Page 4 of 6

presented in Tables 4-6 along with the calculated methane emission by Default Method and FOD Method.

\begin{tabular}{|c|c|c|c|c|c|c|}
\hline & \multicolumn{3}{|c|}{ Correlation } & \multirow[t]{2}{*}{ Mean } & \multirow[t]{2}{*}{ Std. Dev. } & \multirow{2}{*}{ Geometric Increase (\%) } \\
\hline & $\mathrm{BL}$ & $\mathrm{GL}$ & $\mathrm{OL}$ & & & \\
\hline $\mathrm{BL}$ & 1 & & & 65215.8 & 9789 & 9.61 \\
\hline GL & -0.26 & 1 & & 1867657 & 180209 & 5.76 \\
\hline OL & -0.62 & 0.64 & 1 & 34185.7 & 4450 & $-7.75^{*}$ \\
\hline
\end{tabular}

Table 3: Correlation between solid waste reaching landfill sites and their descriptive statistics [17].
Various values and parameters required for calculation of methane emission potential are described in the methodology. The discussion of the results is discussed here.

\section{Bhalswa landfill (BL)}

Bhalswa Landfill was started in 1992 and receives household, vegetable market and Cand $D$ waste. It receives around 1500 tonne per day of wastes from Civil Lines, Karol Bagh, Rohini, Narela, Najafgarh and West Delhi Area. It is a major source of ground water pollution. The quantity of solid waste received at $\mathrm{BL}$ and the respective methane emission by IPCC-Default method and IPCC-FOD Methods are given in Table 4. The emissions have been found to gradually decrease from $127.66 \mathrm{Gg} / \mathrm{yr}$ to $91.23 \mathrm{Gg} / \mathrm{yr}$ by Default method and 86.71 to 61.97 $\mathrm{Gg} / \mathrm{yr}$ by FOD method as the waste reaching this landfill has decreased over the years.

\begin{tabular}{|l|l|l|l|}
\hline Year & MSW received at BL (tons per month) & Methane emission by Default Method (Gg/yr) & Methane emissions by FOD Method (Gg/yr) \\
\hline $2002-2003$ & 69072 & 127.66 & 86.71 \\
\hline $2003-2004$ & 77009 & 142.30 & 96.67 \\
\hline $2004-2005$ & 82773 & 153.00 & 103.91 \\
\hline $2005-2006$ & 60236 & 111.32 & 76.62 \\
\hline $2006-2007$ & 54566 & 100.84 & 68.49 \\
\hline $2007-2008$ & 60674 & 112.13 & 76.17 \\
\hline $2008-2009$ & 69617 & 128.65 & 87.39 \\
\hline $2009-2010$ & 70134 & 129.61 & 88.04 \\
\hline $2010-2011$ & 58711 & 108.50 & 73.70 \\
\hline $2011-2012$ & 49366 & 91.23 & 61.97 \\
\hline
\end{tabular}

Table 4: Methane emissions from Bhalswa landfill (BL).

\section{Ghazipur landfill (GL)}

Ghazipur Landfill was started in 1984 and receives household, animal waste from poultry, fish market and slaughter house. It receives around 2200 tonne per day of wastes from Shahdara (North and West), City zone, Sadar, Pahargunj, NDMC municipal areas. It receives the highest quantity of solid waste to be disposed. The quantity of solid waste received at GL and the respective methane emission by IPCCDefault method and IPCC-FOD Methods are given in Table 5. The quantity of waste reaching GL has increased; hence the $\mathrm{CH}_{4}$ emissions have also been observed to increase gradually from $3125.121 \mathrm{Gg} / \mathrm{yr}$ to $3845.20 \mathrm{Gg} / \mathrm{yr}$ by default method and increased from $2122.85 \mathrm{Gg} / \mathrm{yr}$ to $2611.99 \mathrm{Gg} / \mathrm{yr}$ by FOD method. GL shows the maximum emission as it received the largest quantity of solid waste. Also the methane emissions calculated by First order decay method are less than of Default method.

\begin{tabular}{|l|l|l|l|}
\hline Year & MSW received at GL (tons per month) & Methane emission by Default Method (Gg/yr) & Methane emissions by FOD Method (Gg/yr) \\
\hline $2002-2003$ & 1691083 & 3125.12 & 2122.85 \\
\hline $2003-2004$ & 1907599 & 3525.24 & 2394.65 \\
\hline $2004-2005$ & 1929465 & 3565.65 & 2422.10 \\
\hline $2005-2006$ & 2061538 & 3809.72 & 2587.89 \\
\hline $2006-2007$ & 1903583 & 3517.82 & 2389.61 \\
\hline $2007-2008$ & 1524059 & 2816.46 & 1913.18 \\
\hline $2008-2009$ & 1659741 & 3067.20 & 2083.51 \\
\hline
\end{tabular}


Citation: Singh SK, Anunay G, Rohit G, Shivangi G, Vipul V (2016) Greenhouse Gas Emissions from Landfills: A Case of NCT of Delhi, India. J Climatol Weather Forecasting 4: 157. doi:10.4172/2332-2594.1000157

Page 5 of 6

\begin{tabular}{|l|l|l|l|}
\hline $2009-2010$ & 1845896 & 3411.21 & 2317.20 \\
\hline $2010-2011$ & 2072873 & 3830.67 & 2602.12 \\
\hline $2011-2012$ & 2080736 & 3845.20 & 2611.99 \\
\hline
\end{tabular}

Table 5: Methane emissions from Ghazipur landfill (GL).

\section{Okhla landfill (OL)}

Okhla Landfill was started in 1996 and receives mainly household waste with some $\mathrm{C}$ and $\mathrm{D}$ waste. It receives around 1200 tonne per day of wastes from Central, Najafgarh, South Delhi and Cantonment Board. The quantity of solid waste received at OL and the respective methane emission by IPCC-Default method and IPCC-FOD Methods are given in Table 6. The emissions have been found to gradually decrease from $350.29 \mathrm{Gg} / \mathrm{yr}$ to $77.42 \mathrm{Gg} / \mathrm{yr}$ by default method and increased from $34.16 \mathrm{Gg} / \mathrm{yr}$ to $52.60 \mathrm{Gg} / \mathrm{yr}$ as the waste reaching this landfill has increased but the rate at which waste is received at OL is reducing over time. OL shows a geometric growth rate of $-7.75 \%$ of solid waste received.

\begin{tabular}{|l|l|l|l|}
\hline Year & MSW received at OL (tons per month) & Methane emission by Default method (Gg/yr) & Methane emissions by FOD Method (Gg/yr) \\
\hline $2002-2003$ & 27216 & 50.29 & 34.16 \\
\hline $2003-2004$ & 31180 & 57.62 & 39.14 \\
\hline $2004-2005$ & 30004 & 55.48 & 37.66 \\
\hline $2005-2006$ & 35249 & 65.14 & 44.25 \\
\hline $2006-2007$ & 33736 & 62.34 & 42.35 \\
\hline $2007-2008$ & 30836 & 56.98 & 38.71 \\
\hline $2008-2009$ & 33807 & 62.48 & 42.44 \\
\hline $2009-2010$ & 37379 & 69.08 & 46.92 \\
\hline $2010-2011$ & 40554 & 74.94 & 50.91 \\
\hline $2011-2012$ & 41896 & 77.42 & 52.60 \\
\hline
\end{tabular}

Table 6: Methane emissions from Okhla landfill (OL).

Figure 3 shows the methane emission from years 2002 to 2012 calculated by IPCC- Default method (DM) and FOD Method at BL, GL and OL landfill sites. It is observed that Default Method yields higher value of emission than FOD method because any change in the amount of MSW disposed is reflected immediately in the results of
IPCC-Default method whereas the FOD method responds slowly to the changes. The IPCC-Default Method is easy to implement and the result are also lucid. The FOD method requires adequate knowledge of the decay process at solid waste disposal sites and comparatively more data is required (Table 7).
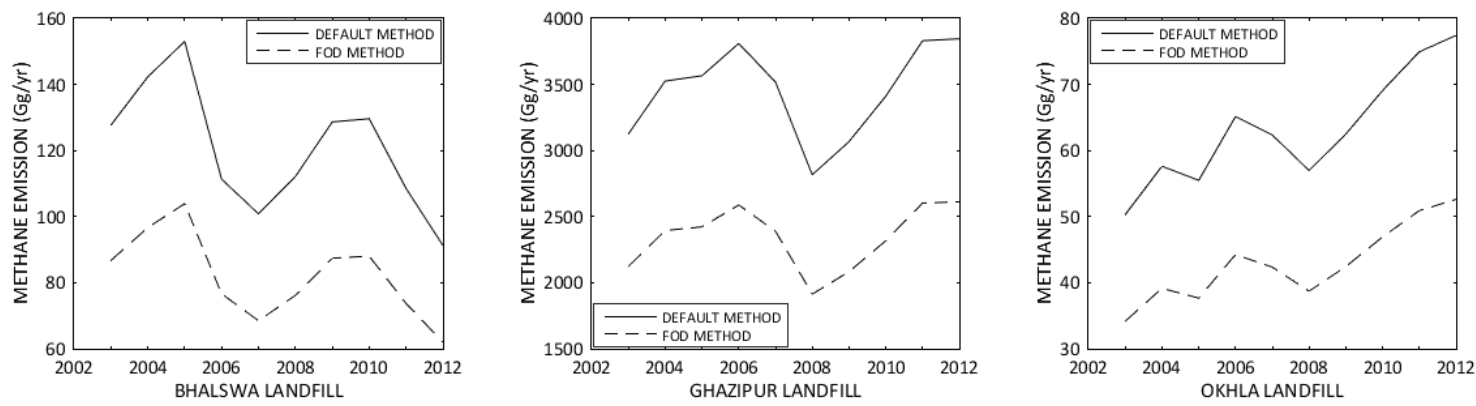

Figure 3: Methane emissions from BL, GL and OL landfill sites (Gg/yr).

In consonance with the total quantity of solid waste received at the landfills, Ghazipur emits the largest share of methane emission from both methods. The variation in methane emissions is found to be fluctuating the most at GL with a standard deviation of 333 in Default Method $\mathrm{CH}_{4}$ emission results and 226.2 in FOD method $\mathrm{CH}_{4}$ emission results. 
Page 6 of 6

\begin{tabular}{|l|l|l|l|l|l|l|}
\hline \multicolumn{2}{|l|l|l|l|}{ BL } & \multicolumn{2}{l|}{ GL } & \multicolumn{2}{l|}{ OL } \\
\hline IPCC Method & DM & FOD & DM & FOD & DM & FOD \\
\hline Mean & 120.5 & 82.0 & 3451.4 & 2344.5 & 63.2 & 42.9 \\
\hline St. Dev. & 18.1 & 12.2 & 333.0 & 226.2 & 8.2 & 5.6 \\
\hline
\end{tabular}

6. Intergovernmental Panel on Climate Change (IPCC) (1996) Report of the Twelfth Season of the Intergovernmental Panel on Climate Change, Mexico City.

7. $\quad$ Singh SK, Singh N (1998) Solid Waste Management of Bathinda City. Proceedings of Thirteenth International Conference on Solid Waste technology and Management. Philadelphia, USA.

Table 7: Descriptive statistics of methane emission from BL, GL and OL landfills.

Uncertainty in quantity and composition of waste received at landfill sites, oxidation mechanism and rate of methane generation in upper crust of landfill, fraction of DOC and DOCF contribute to the uncertainties in GHG emission estimation from landfills. IPCC model that predict the amount of methane generated (mass balance, first order decay) need to be precise for accurate results. Therefore, even a small variation in the DOC or methane generation rate constant may lead to large variations in $\mathrm{CH}_{4}$ emission estimates.

\section{Conclusion}

Municipal solid waste disposal is a significant source of methane emissions globally. The increasing pressure of waste from the population needs an alternative for waste management and disposal other than landfilling in topographic depressions. Present study revealed that the methane emissions from Bhalswa, Ghazipur and Okhla Landfills for the year 2011-2012 was $91.23 \mathrm{Gg} / \mathrm{yr}, 3845.20 \mathrm{Gg} / \mathrm{yr}$ and $77.42 \mathrm{Gg} / \mathrm{yr}$ by Default Method; and $61.97 \mathrm{Gg} / \mathrm{yr}, 2611.99 \mathrm{Gg} / \mathrm{yr}$ and $52.60 \mathrm{Gg} / \mathrm{yr}$ by First Order Decay method. Hence there emerges an urgent need to initiate mitigation steps for controlling GHG emission from landfill areas. Moreover the quantity of methane emission has been increasing as a result of increased consumption. The first step of waste management practice to be employed is the segregation of organic component from solid waste at the source, which will be effective for composting. Secondly, construction of scientifically planned sanitary landfill site with provision of tapping landfill gas for its fuel value [11]. Hence the huge quantity of MSW in Delhi has enormous waste to energy potential $[3,19]$ which if utilized can cater to Delhi's increasing energy needs.

\section{References}

1. Tchobanoglous G, Theisen H, Vigil SA (1993) Integrated Solid Waste Management: Engineering Principles and Management Issues, McGraw Hill International editions, pp: 978.

2. Jhamnani B, Singh SK (2007) Solid Waste Management by land filling in new Urban Growth Centres. National Seminar on Integrated Development of Towns as new growth Centers. Indian Buildings Congress 17-19.

3. Kumar A, Sharma MP (2014) Estimation of GHG emission and energy recovery potential from MSW landfill sites. Sustainable Energy Technologies and Assessments 5: 50-61.

4. Singh SK, Bisht A (2015) Environmental Management in Mass Gatherings, Int J of Engg Sci and Mgmt 5: 130-138.

5. Sahai S, Sharma C, Mitra AP, Singh SK, Gupta PK (2011) Assessment of trace gases, carbon and nitrogen emission from field burning of agricultural residues in India. Nutrient Cycling in Agroecosystems 89: 143-157.

Siddiqui FZ, Khan ME (2011) Landfill gas recovery and its utilization in India: current status, potential prospects and policy implications. J Chem Pharm Res 3: 174-83.

9. Hegde U, Chang TC, Yang SS (2003) Methane and carbon dioxide emissions from Shan chu-ku landfill site in northern Taiwan. Chemosphere 52: 1275-1285.

10. Singh J, Ramanathan AL (2015) Solid Waste Management: Present and Future Challenges. In: Singh SK, Mahour M (eds18.) Clean Development Machanism: An Opportnity in Solid Waste Perspective, pp: 178-185.

11. Singh J, Ramanathan AL (2015) Solid Waste Management: Present and Future Challenges In: Singh SK, Mahour M (eds2.) Methane Estimation from Landfill Site, pp: 19-28.

12. Solomon S, Qin D, Manning M, Chen Z, Marquis M, et al. (2007) Climate Change 2007: The Physical Science Basis, IPCC Fourth Assessment Report.

13. Singh SK (2007) Ground water Modeling-Trends and Practices. Journal of American Society of Civil Engineers-IS 4(1).

14. Chawla A, Singh SK (2014) Modelling of Contaminant Transport from Landfills. International Journal of Engineering Science and Innovative Technology 3: 222-227.

15. Govt. of Delhi, Department of Environment (2015) Waste Management.

16. Chakraborty M, Sharma C, Pandey J, Singh N, Gupta PK (2011) Methane Emission Estimation from Landfills in Delhi: A comparative Assessment of Different Methodologies. Atmospheric Environment 45: 7135-7142.

17. Kumar A (2013) Existing Situation of Municipal Solid Waste Management in NCT of Delhi, India, Research Forum: International Journal of Social Sciences 1: 6-17.

18. Gupta D, Singh SK (2012) Green House Gas Emission from Waste Water Treatment Plants: A Case Study of Noida, India. Journal of Water Sustainability 2: 131-139.

19. Gupta D, Singh SK (2015) Energy use and Greenhouse Gas emissions from Waste Water Treatment Plants, Journal of Environmental Engineering 7: 1-10.

20. Gour AA, Singh SK, Tyagi SK, Mandal A (2013) Weekday/Weekend Differences in Air Quality Parameters in Delhi, India. International Journal of Research in Engineering and Technology 1: 69-76.

21. Gour AA, Singh SK, Tyagi SK, Mandal A (2015) Variation in Parameters of Ambient Air Quality in National Capital Territory (NCT) of Delhi (India). Atmospheric and Climate Sciences 5: 13-22.

22. Aenab AM, Singh SK, Lafta AJ (2013) Critical Assessment of Air Pollution by ANOVA Test and Human Health Effects. Atmospheric Environment 71: 84-91.

23. Municipal Corporation of Delhi (2004) Feasibility study and master plan for Optimal Waste Treatment and Disposal for the Entire State of Delhi on Public Private Partnership Solution. Volume 6: Municipal Solid Waste Characterization Report.

24. Sastry DBSSR. Composition of Municipal Solid Waste- Need for Thermal Treatment in the present Indian context.

25. Frøiland-Jensen JE, Pipatti R. $\mathrm{CH}_{4}$ emissions from Solid Waste Disposal. Good Practice Guidance and Uncertainty Management in National Greenhouse Gas Inventories 419-439. 